\title{
Examining relationship between service quality, user satisfaction and performance impact in the context of smart government in UAE
}

\author{
Ali Ameen ${ }^{1}$, Dawoud Al-Ali ${ }^{2}$, Osama Isaac ${ }^{3}$, Fathey Mohammed ${ }^{4}$ \\ ${ }^{1,2,3}$ Faculty of Business and Accountancy, Lincoln University College, Malaysia \\ ${ }^{4}$ School of Computing, Universiti Utara Malaysia (UUM), Malaysia
}

\begin{tabular}{|c|c|}
\hline Article Info & ABSTRACT \\
\hline Article history: & Governments attempt to use all forms of information technologies including \\
\hline Received Mar 30, 2020 & Internet and mobile computing to be able to transform relationships with \\
\hline Revised May 6, 2020 & technology innovation output and government's vision in United Arab \\
\hline Accepted May 18, 2020 & $\begin{array}{l}\text { Emirates (UAE). In this regard, investigating the relationship between } \\
\text { service quality, user satisfaction, and performance impact may help }\end{array}$ \\
\hline Keywords: & $\begin{array}{l}\text { the government to mark its current progress and milestone achievement. } \\
\text { This research proposed a model based on Delone \& McLean IS success }\end{array}$ \\
\hline Perform & model by considering the research context. The modeling of structural \\
\hline Service quality & equations via PLS (Partial least squares) regression was applied to evaluate \\
\hline Smart government & $\begin{array}{l}\text { the model within the context of public sector in the UAE. The data was } \\
\text { collected from a sample of } 147 \text { employees in public organizations using }\end{array}$ \\
\hline UAE & a questionnaire. Results demonstrated that the quality of service has \\
\hline User satisfaction & $\begin{array}{l}\text { a significant effect on user satisfaction. In addition, quality of service and } \\
\text { user satisfaction positively influences the staff performance. The outcome of } \\
\text { this research helps to enhance the understanding of the impact of smart } \\
\text { government applications. }\end{array}$ \\
\hline
\end{tabular}

Copyright $\odot 2020$ Institute of Advanced Engineering and Science. All rights reserved.

\section{Corresponding Author:}

Ali Ameen,

Faculty of Business and Accountancy,

Lincoln University College,

Selangor, Malaysia

Email: ali.ameen@aol.com

\section{INTRODUCTION}

Internet has rapidly become vital to the majority of our routine activities and has considerably affected every facet of organisational functioning [1]. It plays an important role in the management of information which in turn is used to improve decision making process, quality of communication, efficiency of operations and knowledge acquirement [2-5].

One of the United Arab Emirates (UAE) Vision 2021 pillars is transforming to competitive knowledge economy (innovation, creativity, and financial services) using innovative technologies. Organizational innovation and smart government initiative are drivers of achieving the goal. The current smart and e-governance systems should continuously be evaluated, service delivery quality should be improved, and transparency and accountability of the UAE Government should be enhanced.

The government of UAE emphasizes that it's vision and long-term strategy is to always strive to be number one in the world in all aspects including technology usage. According to Global Innovation Index 2017, UAE is ahead its neighbours in ICT access and innovation output; however, it has some kind of inconsistency between the two indicators where innovation output is significantly low compared to the level of ICT access. The new generation of ICT transforms public services into a Smart Government. The concept 
of the 'SMART' stands for the main feature of new technology which is social, mobile, analytics, radical-openness trust [6-12] .

Although innovativeness is being increasingly investigated in the academic literature as an important variable in the context of technology adoption and its impact, there is a clear gap between the indicator of the impact of technology innovation output and UAE government's vision of the future in this regard. More specifically, there is lack of empirical studies examining the relationship between service quality, user satisfaction, and performance impact in the context of smart government in UAE. To be able to reduce this discrepancy, this research addresses the relationship between the quality of service in smart government initiative and users' satisfaction, and the impact of these two factors on the performance of public sector organizations in UAE. The paper is organized so that the proposed model is introduced by identifying the constructs and related hypotheses. Then, the applied research method is described. Next, data analysis and results are reported. Finally, results discussion and conclusion is presented.

\section{THE PROPOSED MODEL}

The correlations between the proposed factors are conjectured in a conceptual model based on Delone and McLean IS success model [13]. Figure 1 displays the proposed model which includes service quality, user satisfaction and performance impact. Delone \& Mclean developed the information system success model, which known as DMISM, to comprehensively review IS success factors. Six categories of IS success factors were concluded including system quality, information quality, IS use, user satisfaction, individual impact, and organizational impact [6, 14-19]. Then in 2003, the model was updated by the same authors (Delone \& Mclean) by including service quality as a new dimension. Further, all impact measurements were grouped into one category called "net benefit", to avoid complicating the model with more success measurements [20-22]. The proposed model examines the correlation between service quality, user satisfaction and performance in the context of smart government services in UAE. Accordingly, the proposed conceptual model has three hypotheses to be tested. The following sub sections define the model constructs and related hypotheses.

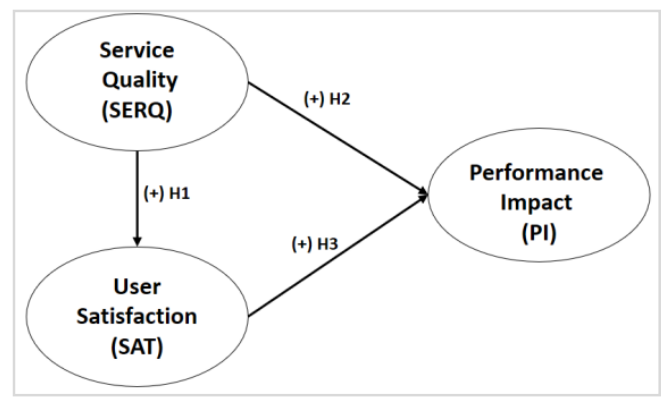

Figure 1. The proposed conceptual model

\subsection{Service quality (SERQ)}

Service quality means the fulfilment of service provided to meet customer needs, satisfaction and expectations [23]. With reference to the research of IS, in their restructured IS success model, Delone and McLean [24] have defined service quality using these characteristics: reliability, tangibles, assurance, responsiveness, and empathy. Delone \& McLean [24] proposed that the service quality stands for user support by the department of IS, and is often assessed by the reliability, responsiveness and empathy [24]. Oktal et al. [25] examined the impact of service quality on user satisfaction as well as the impact of performance and stated its importance on both relationships [25]. As a result, the below hypotheses are proposed:

H1: Service quality significantly influences user satisfaction.

$\mathrm{H} 2$ : Service quality significantly influences performance impact.

\subsection{User satisfaction (SAT)}

User satisfaction is considered as one of the central aspects in IS discipline [26-30]. Thus, it has been tested extensively in studying the use of systems and applications [25]. User satisfaction is defined as the attitude of the user towards a computer system/application he interacts with [31]. It is the extent to which the user thinks application/system fulfils his/her requirements. In addition, user satisfaction is considered as 
a measure of whether the user thinks that the system is useful and he wishes to use it again [25, 32, 33]. User satisfaction and performance are key constructs of the Delone and McLean IS success model, thus the relationship between these two constructs has been confirmed widely in the literature. Alshamsi, et al., [7] examined and confirmed the significance of the relationship between using smart government services and user satisfaction. As a result, the following hypothesis is proposed:

H3: User satisfaction has a significant influence on performance impact.

\subsection{Performance impact (PI)}

The performance impact is the definitive measurement regarding the use of an IS, as being a key aspect in the Delone and Mclean IS success model [2]. It has extensively been the focus of several studies in this domain. Aparicio et al., [34] investigated factors that influence the performance impact of using e-learning systems. Furthermore, a study by Tam and Oliveira [35] in Portugal examined the performance impact of using mobile learning.

\section{RESEARCH METHOD}

The research method for this study involved creating a questionnaire of 13 items. The questionaire items were developed by adapting the orginal measurments from the literature of IS in the context of the study. The questionnaire used Likert scale suggested by [36], and applied in the previous studies in the similar context $[20,32,37,38]$. The data was collected using a self-managed questionnaire between January 2017 and March 2018. Employees in governmental organisations in UAE were targeded. 200 questionnaires were distrbuted, and 160 were returned. After data screening process, 15 responses were droped. According to Krejcie and Morgan [39] and Tabachnick and Fidell [40], the sample size (145) is sufficient. Structural Equation Modelling-Variance Based (SEM-VB) was used to assess the proposed model by utilising SmartPLS 3.0 [41]. Using PLS, measurement and structural model simultaneously can be analysed which results in more accurate estimates [42]. Table 1 illustrates the demographic data of the respondents.

Table 1. Respondents' profiles

\begin{tabular}{|c|c|c|}
\hline Demographic Item & Categories & Persentage \\
\hline \multirow{4}{*}{$\begin{array}{l}\text { Do you use e- } \\
\text { government services } \\
\text { Gender }\end{array}$} & Yes & $100 \%$ \\
\hline & No & $0 \%$ \\
\hline & Male & $53.1 \%$ \\
\hline & 2. Female & $46.9 \%$ \\
\hline \multirow[t]{3}{*}{ Age } & 1. 24-29 years & 15.9 \\
\hline & $30-39$ years & 24.2 \\
\hline & 3. 40 and more & 59.9 \\
\hline \multirow[t]{2}{*}{ Nationality } & 1. Local & $62 \%$ \\
\hline & 2. International & $38 \%$ \\
\hline \multirow[t]{3}{*}{ Education level } & 1. Secondary School & $18.4 \%$ \\
\hline & 2. Undergraduate & $64.7 \%$ \\
\hline & 3. Postgraduate & $16.9 \%$ \\
\hline \multirow[t]{4}{*}{ Occupation } & 1. Study or ICT & $34.5 \%$ \\
\hline & 2. Work in Services & $28.0 \%$ \\
\hline & 3. Work in Planning & $22.4 \%$ \\
\hline & 4. Others & $15.1 \%$ \\
\hline \multirow{4}{*}{$\begin{array}{l}\text { Online service Access } \\
\text { rate }\end{array}$} & Daily & $39.8 \%$ \\
\hline & 2. Weekly & $22.9 \%$ \\
\hline & 3. Monthly & $24.2 \%$ \\
\hline & Occasionally & $13.1 \%$ \\
\hline \multirow{4}{*}{$\begin{array}{l}\text { Session time (in } \\
\text { minutes) }\end{array}$} & $0-10$ & $36.3 \%$ \\
\hline & $11-20$ & $23.2 \%$ \\
\hline & 3. $21-30$ & $15.9 \%$ \\
\hline & 4. $>30$ & $24.7 \%$ \\
\hline
\end{tabular}

\section{RESULTS}

Based on partial least squares (PLS), two-stage analytical technique; measurement model assessment (verifying the reliability and validityof the instrument) and structural model assessment (examining the hypothesized relationships) was applied after reporting the descriptive results [43]. According to Hair et al., [43], the measurement model examines each construct's scale, and the structural model examines the correlation between the constructs in the model. PLS technique is capable of analysis the structural and measurement model simultaneously with a significant degree of accuracy [14, 44-49]. 


\subsection{Descriptive analysis}

Table 2 shows the results of standard deviation (SD) and mean of every parameter scale in the instrument. The respondents were asked to reveal their opinion regarding service quality, user satisfaction, and performance impact based on a 5-point Likert scale varying from 5 (strongly agree) to 1 (strongly disagree). The score of the impact of performance was the highest with 3.263 mean and SD of 1.018 .

Table 2. Descriptive results and reliability indicators

\begin{tabular}{|c|c|c|c|c|c|c|c|}
\hline Construct & Items & $\begin{array}{c}\text { Loading } \\
(>0.5)\end{array}$ & Mean & SD & $\begin{array}{c}\alpha \\
(>0.7)\end{array}$ & $\begin{array}{c}\text { CR } \\
(>0.7)\end{array}$ & $\begin{array}{c}\text { AVE } \\
(>0.5)\end{array}$ \\
\hline Service & SERQ_1 & 0.943 & & & & & \\
\hline Quality & SERQ_2 & 0.939 & 3.189 & 1.157 & 0.942 & 0.963 & 0.897 \\
\hline (SERQ) & SERQ_3 & 0.958 & & & & & \\
\hline User & SAT_1 & 0.933 & & & & & \\
\hline \multirow{4}{*}{$\begin{array}{l}\text { Satisfaction } \\
\quad(\mathrm{SAT})\end{array}$} & SAT_2 & 0.926 & 3.109 & 1.107 & 0.922 & 0.950 & 0.865 \\
\hline & SAT_3 & 0.930 & & & & & \\
\hline & PI_1 & 0.872 & & & & & \\
\hline & PI_2 & 0.877 & & & & & \\
\hline Performance & PI_3 & 0.909 & & & & & \\
\hline Impact & PI_4 & 0.916 & 3.263 & 1.018 & 0.952 & 0.962 & 0.808 \\
\hline \multirow[t]{3}{*}{$(\mathrm{PI})$} & PI_5 & 0.910 & & & & & \\
\hline & PI_6 & Deleted & & & & & \\
\hline & PI_7 & 0.909 & & & & & \\
\hline
\end{tabular}

\subsection{Assessment of measurement model}

Reliability and validity (comprising discriminant and convergent validity) of the constructs' measurments were assessed in this stage. Cronbach alpha $(\alpha)$ was tested to assess the reliability of each construct in the model. The cronbach alpha scores of all constructs ranged from 0.922 to 0.952 , which exceeded the satisfaction value of 0.7 [50-52]. In addition, for inspecting the reliability, the composite reliability (CR) values were reported. CR values ranged from 0.950 to 0.963 , which also were greater than 0.7 [53-56] in Table 2. Thus, construct reliability has been fulfilled for all constructs. In addition, indicator reliability assessment was conducted by examining factor loadings. As per Hair et al. [50], the values exceeding 0.70 suggest substantial factor loadings. Table 1 shows that all items have factor loadings' values greater than the suggested value of 0.7 except PI_6 which was droped from PI scale because of low loading.

For the convergent validity assessment, AVE (average variance extracted) was examined. AVE is refered as the degree to which an item is correlated positively with the items in the same construct. All the AVE scores ranged from 0.808 to 0.897 , which is beyond the minimum criteria of 0.50 [57]. Thus, all constructs have convergent validity as shown in Table 2 .

The degree to which each construct is distinct and captures a phenomenan not represented by other constructs is refered as discriminant validity. Cross-loadings and Fornell-Larcker criterian were used to assess the discriminant validity. Cross-loadings measurement is applied as the initial step in examining discriminant validity [43]. The results show that the items' outer loadings on each construct exceed all the outer loadings with other constructs. This indicates that the cross-loading assessment had met the requirements as shown in Table 3.

Table 3. Constructs'cross loadings

\begin{tabular}{cccc}
\hline & SERQ & SAT & PI \\
\hline SERQ_1 & .943 & .552 & .601 \\
SERQ_2 & .939 & .534 & .580 \\
SERQ_3 & .958 & .541 & .578 \\
SAT_1 & .547 & .933 & .625 \\
SAT_2 & .509 & .926 & .588 \\
SAT_3 & .541 & .930 & .590 \\
PI_1 & .573 & .633 & .872 \\
PI_2 & .558 & .581 & .877 \\
PI_3 & .566 & .548 & .909 \\
PI_4 & .550 & .567 & .916 \\
PI_5 & .569 & .603 & .910 \\
PI_7 & .517 & .545 & .909 \\
\hline Key: SERQ: service quality, SAT: user satisfaction, PI: performance impact
\end{tabular}

Examining relationship between service quality, user satisfaction, and performance impact ... (Ali Ameen) 
Further, for discriminant validity assessment, Fornell-Larcker measurement is applied. The results indicate that $\sqrt{ }$ AVE for each construct is greater than the inter-correlations with other constructs as shown in Table 4, which demonstrates that each construct is distinct [58-59]. According to Hair et al., [43], this indicates that all constructs had fulfilled discriminant validity.

Table 4. Fornell-Larcker criterion results

\begin{tabular}{ccccc}
\hline \multicolumn{5}{c}{ Table 4. Fornell-Larcker criterion results } \\
& \multirow{2}{*}{ Factors } & 1 & 2 & 3 \\
& PI & SERQ & SAT \\
\hline 1 & PI & $\mathbf{0 . 8 9 9}$ & & \\
2 & SERQ & 0.619 & $\mathbf{0 . 9 4 7}$ & \\
3 & SAT & 0.647 & 0.573 & $\mathbf{0 . 9 3 0}$ \\
\hline \multicolumn{2}{l}{ Note: Highlighted values represent } & $\sqrt{ }$ AVE while the others represent the correlations
\end{tabular}

\subsection{Assessment of structural model}

To test the proposed hypotheses, the significance of each path is estimated using a PLS bootstrapping method with 5000 resamples. Verifying the hypotheses involves calculating path coefficients (beta $\beta$ ), its corresponding $t$-values and $R^{2}$ [43]. The value of the $\beta$ indicates the strengths of relationships between the constructs. In addition, the $\mathrm{R}^{2}$ value represents the amount of variance explained by independent variables.

Table 5 and Figure 2 illustrate the assessment of structural model representig the results of the hypothesis testing, where all the 3 hypotheses are examined. Service quality considerably predicts user satisfaction. Hence, $\mathrm{H} 1$ is supported with $(\beta=0.573, \mathrm{t}=15.809, \mathrm{p}<0.001)$. Service quality and user satisfaction significantly predict performance impact. Hence, $\mathrm{H} 2$ and $\mathrm{H} 3$ are supported with $(\beta=0.370$, $\mathrm{t}=8.432, \mathrm{p}<0.001)$ and $(\beta=0.435, \mathrm{t}=10.376, \mathrm{p}<0.001)$, respectively.

The strength of the correlations between the constructs is evaluated by the path coefficients, and in this case, the results demonstrate that the straightforward consequences of user satisfaction on the performance impact are stronger than the effects of quality of service on the performance impact. Furthermore, the $R^{2}$ values show adequate level of descriptive power, suggesting a substantial model [60-62].

Table 5. Structural model assessment results

\begin{tabular}{|c|c|c|c|c|c|c|c|}
\hline Hypothesis & Relationship & Std Beta & Std Error & t-value & p-value & Decision & $\mathrm{R}^{2}$ \\
\hline $\mathrm{H} 1$ & $\mathrm{SERQ} \rightarrow \mathrm{SAT}$ & 0.573 & 0.036 & 15.809 & 0.000 & Supported & 0.33 \\
\hline $\mathrm{H} 3$ & $\mathrm{SAT} \rightarrow \mathrm{PI}$ & 0.435 & 0.042 & 10.376 & 0.000 & Supported & \\
\hline
\end{tabular}

Key: SERQ: service quality, SAT: user satisfaction, PI: performance impact

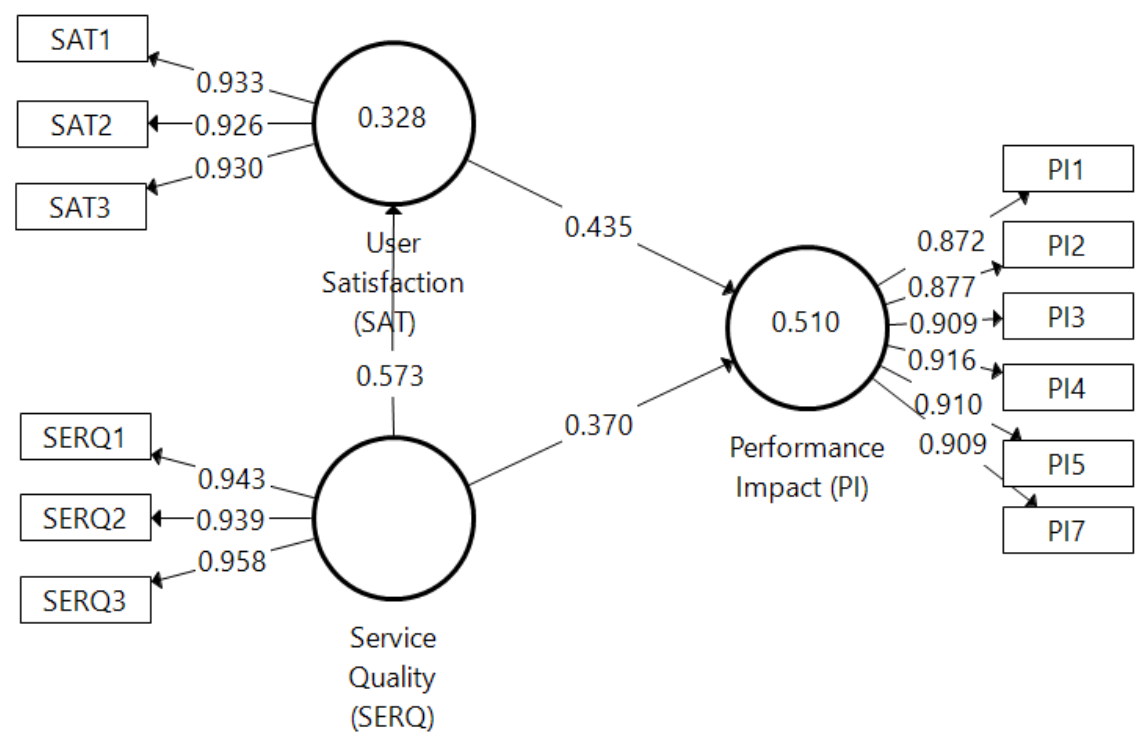

Figure 2. PLS algorithm results 


\section{DISCUSSION}

Service quality was found to positively influences user satisfaction in using smart government services among employees in public sector in the UAE, which is supported by previous studies $[6,19,20,38,63-66]$. It is explained by the fact that the more the employee is able to use smart government services at the time or place he/she wants, find platforms that are relevant to his tasks, and is able to communicate interactively through it, the more the employees consider their use of smart government services to be a wise decision, as it meets their expectations, and leaves them feeling generally satisfied.

It was also discovered that the quality of service significantly affected performance impact. This effect, which is supported by past studies [32, 33, 37, 67-69], has been described by the idea that when a staff member of a public sector organisation is able to utilise smart government applications at the place or time he/she wishes, find platforms appropriate for his tasks, and is also able to be in touch interactively using it, then this will bring about a performance enhancement in 3 perspectives: efficiency (complete tasks easily and quickly), knowledge acquisition (acquire new skills and knowledge, generate innovative ideas) and improve communication with clients and employees, besides decision quality and service delivery.

In the long run, user satisfaction was discovered to positively influence the impact of performance of smart government applications among staff members within public sector organisations in the UAE. This effect is supported by the past studies [70-72], and is justified by the fact that when staff members in public sector organisations are already satisfied with the application, it will make a contribution to their performance improvement in 3 perspectives: efficiency, knowledge acquirement and with regards to communication with clients and employees, besides decision quality and service delivery.

\section{CONCLUSION}

Even though the governmental organisations of UAE are ahead of their regional peers in terms of performance, it is trying hard to enhance the services of its public sector institutions, the results of this research could be regarded as one of the proposals that can be used in this direction. The aim of this research was to test the impact of technology attributes quality of service on user satisfaction as well as impact of performance of smart government applications on the employees in the public sector organisations in the UAE. It has offered a case to authenticate parts of Delone \& McLean IS success model and, despite various restrictions faced by the research; it has been able to give an insight into a new context of smart governments. The results revealed that all three hypotheses were significant, and the independent variables significantly explain $51 \%$ of performance impact.

\section{REFERENCES}

[1] F. S. Al-Obaithani and A. A. Ameen, "Toward Proposing Smart-Government Maturity Model: Best Practices, International Standards, and Six-Sigma Approach," in 1st International Conference on Management and Human Science (ICMHS 2017), pp. 124-137, 2017.

[2] W. H. DeLone and E. R. McLean, "Information Systems Success Measurement," Foundations and Trends in Information Systems, vol. 2, no. 1, pp. 1-116, 2016.

[3] R. Cheung and D. Vogel, "Predicting user acceptance of collaborative technologies: An extension of the technology acceptance model for e-learning," Computers and Education, vol. 63, pp. 160-175, 2013.

[4] W. Cheung, et al., "Prediction of Internet and World Wide Web usage at work: A test of an extended Triandis model," Decision Support Systems, vol. 30, no. 1, pp. 83-100, 2000.

[5] M. K. Chang, et al., "Literature derived reference models for the adoption of online shopping," Information and Management, vol. 42, no. 4, pp. 543-559, 2005.

[6] R. Alshamsi, et al., "Impact of Smart Government Usage and Smart Government Effectiveness on Employee Happiness," Test Engineering and Management, vol. 82, pp. 12086-12100, 2020.

[7] O. Alshamsi, et al., "Examining the Impact of Dubai Smart Government Characteristics on User Satisfaction," International Journal of Recent Technology and Engineering, vol. 8, no. 2S10, pp. 319-327, 2019.

[8] O. Alshamsi, et al., "Towards a Better Understanding of Relationship between Dubai Smart Government Characteristics and Organizational Performance," International Journal of Recent Technology and Engineering, vol. 8, no. 2S10, pp. 310-318, 2019.

[9] K. Alghawi, et al., "The Role of Smart Government Characteristics for Enhancing UAE's Public Service Quality," International Journal on Emerging Technologies, vol. 10, no. 1a, pp. 1-7, 2019.

[10] S. Albreiki, et al., "Impact of Internal Government Efficiency and Service Delivery Infrastructure on the Smart Government Effectiveness in UAE," Int. Journal on Emerging Technologies, vol. 10, no. 1a, pp. 124-131, 2019.

[11] S. Albreki, et al., "The Influence of Knowledge Management on the Smart Government Effectiveness: An Empirical Study in UAE," International Journal on Emerging Technologies, vol. 10, no. 1a, pp. 105-114, 2019.

[12] F. Al-Obthani and A. Ameen, "Association between Transformational Leadership and Smart Government among Employees in UAE Public Organizations," International Journal on Emerging Technologies, vol. 10, no. 1a, pp. 98-104, 2019.

Examining relationship between service quality, user satisfaction, and performance impact ... (Ali Ameen) 
[13] S. Petter, et al., "Information systems success: The quest for the independent variables," Journal of Managememnt Information Systems, vol. 29, no. 4, pp. 7-62, 2013

[14] Y. Alkatheeri, et al., "The Mediation Effect of Management Information Systems on the Relationship between Big Data Quality and Decision making Quality," Test Engineering and Management, vol. 82, pp. 12065-12074, 2020.

[15] M. Rahmah, et al., "The Moderation Effect of Technology Usage on the Relationship between Organizational Innovation and Organizational Learning," Test Engineering and Management, vol. 82, pp. 12114-12128, 2020.

[16] P. B. Giang and A. A. Ali, "Big event and its values to build trust in destination image - a perspective in big cities in vietnam," International Journal of Recent Trends in Business and Tourism, vol. 4, no. 1, pp. 1-6, 2020.

[17] S. Salama, et al., "Impact of Availability of Knowledge Management Infrastructure on Improving the Performance of The Education Sector Staff in Libya: Organizational Loyalty as a Mediating Variable," International Journal of Management and Human Science, vol. 4, no. 1, pp. 29-39, 2020.

[18] P. Sudhana, et al., "A multi-theoretical framework to better understand the college major choice in arts and design," Journal of Applied Research in Higher Education, 2020.

[19] R. Alshamsi, et al., "Investigating the Mediating Effect of Organizational Innovation on the relationship between Smart Government Usage and Employee Happiness," Test Engineering and Management, vol. 83, pp. 12233-12244, 2020.

[20] H. Almarri, et al., "The Mediating Effect of Facilitating Conditions on The Relationship Between Actual Usage of Online Social Networks (OSN) and User Satisfaction," International Journal of Psychosocial Rehabilitaion, vol. 24, no. 06, pp. 6389-6400, 2020.

[21] Y. Alkatheeri, et al., "The Effect of Big Data on the Quality of Decision-Making in Abu Dhabi Government Organisations," in Proceedings of ICDMAI 2019, Data Management, Analytics and Innovation, vol. 2, pp. 231-248, 2019.

[22] A. Haddad, et al., "The Impact of Technology Readiness on the Big Data Adoption Among UAE Organisations," in Data Management, Analytics and Innovation, pp. 249-264, 2020.

[23] A. Parasuraman, et al., "A Conceptual Model of Service Quality and It's Implications for Future Research," Journal of Marketing., vol. 49, no. 4, pp. 41-50, 1985.

[24] S. Petter, et al., "Measuring information systems success: models, dimensions, measures, and interrelationships," European Journal of Information Systems, vol. 17, no. 3, pp. 236-263, 2008.

[25] O. Oktal, et al., "Measurement of internal user satisfaction and acceptance of the e-justice systems in Turkey," Aslib Journal of Information Management, vol. 68, no. 6, pp. 716-735, 2016.

[26] R. Al-Dhamari, et al., "Are audit committee characteristics important to the internal audit budget in Malaysian firms?" Contaduria y Administracion, Accounting and Management, vol. 63, no. 2, pp. 21-22, 2018.

[27] M. S. Afshar, et al., "Audit management, need for closure and detection of misstatements," Journal of Accounting in Emerging Economies, vol. 9, no. 2, pp. 237-250, 2019.

[28] B. A. Al-Gamrh and R. A. Al-Dhamari, "Firm characteristics and corporate social responsibility disclosure," International Business Management, vol. 10, no. 18, pp. 4283-4291, 2016.

[29] R. A. Al-Dhamari, et al., "Board diversity and corporate payout policy: Do free cash flow and ownership concentration matter?" Corporate Ownership and Control, vol. 14, no. 1-2, pp. 373-383, 2016.

[30] B. Al-Gamrh, et al., "The role of corporate governance strength in crisis and non-crisis times," Applied Economics, vol. 50, no. 58, pp. 6263-6284, 2018.

[31] I. Alrajawy, et al., "Examine Factors Influencing the Intention to use Mobile Learning in Yemen Public Universities," Asian Journal of Information Technology, vol. 16, no. 2, pp. 287-297, 2017.

[32] A. Ameen, et al., "Determining Underlying Factors that Influence Online Social Network Usage Among Public Sector Employees in the UAE," in International Conference of Reliable Information and Communication Technology, pp. 945-954, 2018.

[33] A. Ameen, et al., "The Impact of Knowledge Sharing on Managing Organizational Change within Abu Dhabi National Oil Organizations," International Journal of Management and Human Science, vol. 2, no. 3, pp. 27-36, 2018.

[34] M. Aparicio, et al., "Grit in the path to e-learning success," Computers in Human Behavior, vol. 66, pp. 388-399, 2017.

[35] C. Tam and T. Oliveira, "Understanding the impact of m-banking on individual performance: DeLone \& McLean and TTF perspective," Computer in Human Behavior, vol. 61, pp. 233-244, 2016.

[36] B. C. Lee, et al., "Learners' acceptance of e-learning in South Korea: Theories and results," Computer and Education, vol. 53, no. 4, pp. 1320-1329, 2009.

[37] A. Ameen, et al., "Investigating the Key Factors Influencing the Use of Online Social Networks in Public Sector Context in the UAE," International Journal of Innovation, vol. 7, no. 3, pp. 392-411, 2019.

[38] H. Almarri, et al., "Antecedents And Outcomes of Online Social Networks (OSN) Usage among Public Sector Employees," International Journal of Psychosocial Rehabilitation, vol. 24, no. 06, pp. 6373-6388, 2020.

[39] R. V Krejcie and D. W. Morgan, "Determining sample size for research activities," Educational and Psychological Measurement, vol. 30, pp. 607-610, 1970.

[40] B. G. Tabachnick and L. S. Fidell, "Using Multivariate Statistics," 6th ed. Pearson, 2012.

[41] C. M. Ringle, et al., "SmartPLS 3. Boenningstedt: SmartPLS," 2015. [Online], Available: http://www.smartpls.com

[42] D. W. Barclay, et al., "The partial least square (PLS) approach to causal modeling: Personal computer adoption and use as an illustration," Technology Studies, vol. 2, no. 2, pp. 285-309, 1995. 
[43] J. F. Hair, et al., "A Primer on Partial Least Squares Structural Equation Modeling (PLS-SEM)," 2nd ed, London, Thousand Oaks, SAGE, 2017.

[44] O. Isaac, et al., "Perceived Usefulness, Perceived Ease of Use, Perceived Compatibility, and Net Benefits: an empirical study of internet usage among employees in Yemen," in The 7th International Conference Postgraduate Education (ICPE7), pp. 899-919, 2016.

[45] A. Al-Mulla, et al., "The Effect of Organizational Tensions, Merge Policy and Knowledge Sharing on Managing Organizational Change: The Context of Abu Dhabi National Oil Organizations," Journal of Engineering and Applied Science, vol. 14, no. 8, pp. 2517-2531, 2019.

[46] P. Bastola, et al., "The Effect of E-Learning Actual Use on the Net Benefit among Public Universities Students in Nepal," in 22nd International Conference on IT Applications and Management (ITAM), pp. 158-164, 2019.

[47] O. Isaac, et al., "Examining the Relationship Between Overall Quality, User Satisfaction and Internet Usage: An Integrated Individual, Technological, Organizaional and Social Perspective," Asian Journal of Information Technology, vol. 16, no. 1, pp. 100-124, 2017.

[48] O. Isaac, et al., "Towards a Better Understanding of Internet Technology Usage by Yemeni Employees in the Public Sector: An Extension of the Task-Technology Fit (TTF) Model," Research Journal of Applied Sciences, vol. 12, no. 2, pp. 205-223, 2017.

[49] I. Alrajawy, et al., "Mobile Learning in Yemen Public Universities: Factors Influence Student's Intention to Use," in The 7th International Conference Postgraduate Education (ICPE7), pp. 1050-1064, 2016.

[50] V. R. Kannana and K. C. Tan, "Just in time, total quality management, and supply chain management: understanding their linkages and impact on business performance," Omega, vol. 33, no. 2, pp. 153-162, 2005.

[51] F. Al-Obthani and A. Ameen, "Influence of Overall Quality and Innovativeness on Actual Usage of Smart Government: An Empirical Study on the UAE Public Sector," International Journal of Emerging Technologies, vol. 10, no. 1a, pp. 141-146, 2019.

[52] B. A. Alneyadi, et al., "Moderating Effect of Organizational Culture on Relationship between Transformational Leadership and Human Capital: An Empirical Study on Public Sector of UAE," International Journal of Emerging and Technologies, vol. 10, no. 1a, pp. 23-31, 2019.

[53] C. E. Werts, et al., "Intraclass reliability estimates: Testing structural assumptions," Educational and Psychological Measurement, vol. 34, no. 1, pp. 25-33, 1974.

[54] R.B. Kline, "Principles and practice of structural equation modeling," 3rd ed. New York, The Guilford Press, 2010.

[55] D. Gefen, et al., "Structural equation modeling and regression: Guidelines for research practice," Communications of the Association for Information Systems, vol. 4, no. 1, pp. 1-79, 2000.

[56] D. Gefen and D. Straub, "The Relative Importance of Perceived Ease of Use in IS Adoption: A Study of E-Commerce Adoption," Journal of the Association for Information Systems, vol. 1 no. 8, pp. 1-28, 2000.

[57] J. F. Hair, et al., "Multivariate Data Analysis," Pearson New International Edition, 2010.

[58] C. S. Chen, "Perceived risk, usage frequency of mobile banking services," Managing Service Quality: An International Journal, vol. 23, no. 5, pp. 410-436, 2013.

[59] G. Chen, et al., "A multilevel study of leadership, empowerment, and performance in teams," Journal of Applied Psychology, vol. 92, no. 2, pp. 331-346, 2007

[60] L. Cohen, et al., "Research Methods in Education," Routledge, New York, 2007.

[61] S. Cohen and N. Kaimenakis, "Intellectual Capital and Corporate Performance in Knowledge-Intensive SMEs," Learning Organization, vol. 14, no. 3, pp. 241-262, 2007.

[62] G. Chen, et al., "Conflict Management for Effective Top Management Teams and Innovation in China," Journal of Management Studies, vol. 42, no. 2, pp. 277-300, 2005.

[63] M. Rahmah, et al., "Effect of Organizational Innovation (Product Innovation, Process Innovation, and Administrative Innovation) On Organizational Learning," Test Engineering and Management, vol. 82, pp. 12101-12113, 2020.

[64] G. S. A. K. S. Alshamsi, et al., "Impact of Transformational Leadership on Organizational Innovation: Telecommunication Sector of Pakistan," Test Engineering and Management, vol. 82, pp. 14783-14794, 2020.

[65] Y. Alkatheeri, et al., "The Effect of Knowledge Management Quality and Management Information Systems on Decision Making Quality," Test Engineering and Management, vol. 82, pp. 12075-12085, 2020.

[66] A. Althunibat, "Determining the factors influencing students' intention to use m-learning in Jordan higher education," Computers in Human Behavior, vol. 52, no. 1, pp. 65-71, 2015.

[67] A. Ameen and K. Ahmad, "Towards Harnessing Financial Information Systems in Reducing Corruption: A Review of Strategies," Australian Journal of Basic and Applied Sciences, vol. 6, no. 8, pp. 500-509, 2012.

[68] A. Ameen and K. Ahmad, "A Conceptual Framework of Financial Information Systems to reduce corruption," Journal of Theorical and Applied Information Technology, vol. 54, no. 1, pp. 59-72, 2013.

[69] A. Ameen and K. Ahmad, "The Role of Finance Information Systems in anti financial corruptions: A theoretical review," in 11 International Conference on Research and Innovation in Information Systems (ICRIIS'11), pp. 267-272, 2011.

[70] M. Heffernan, et al., "Exploring the HRM-performance relationship: the role of creativity climate and strategy," Employee Relations, vol. 38, no. 3, pp. 438-462, 2016.

[71] L. Para-González, et al., "Exploring the mediating effects between transformational leadership and organizational performance," Employee Relations, vol. 40, no. 2, pp. 412-432, 2018.

[72] K. Dartey-Baah, "Resilient leadership: a transformational-transactional leadership mix," Journal of Global Responsibility, vol. 6, no. 1, pp. 99-112, 2015. 